\author{
Kuprina N. \\ Ph.D., Associate Professor \\ Department of Accounting and Auditing \\ E-mail:k.natali_@ukr.net \\ ORCID ID: 0000-0003-4645-545X \\ Volodina 0. \\ Assistant \\ Department of Foreign Languages \\ E-mail: volodinaolenaonaft@gmail.com \\ ORCID ID: 0000-0003-0552-6733
}

\author{
Markova T. \\ Ph.D., Associate Professor \\ Department of Accounting and Auditing \\ E-mail: markova.tetiana17@gmail.com \\ ORCID ID: 0000-0002-9437-2635 \\ Stupnytska M. \\ The student of the fourth grade of Management, \\ Marketing and Logistics Faculty \\ Odessa National Academy of Food Technologies \\ Kanatna str., 112, Odesa, Ukraine, 65039 \\ E-mail: marino4ka036@gmail.com \\ ORCID ID: 0000-0003-0736-6411
}

\title{
PECULIARITIES OF ANALYSIS OF ENTERPRISE'S OWN CAPITAL IN MODERN CONDITIONS
}

The article deals with the structure of the company's own capital and the definition and formation of its individual elements, such as registered and reserve capital, in accordance with the normative accounting documents and legislative acts of Ukraine. The classification of the equity (invested and accumulated capital) of the enterprise by the National (Regulation) accounting standard 1 "General requirements for financial statements" and by sources of its formation has been considered. The necessity of formation and use of a comprehensive approach to the financial analysis of the company's equity in the management system has been analyzed and substantiated. The scientific result of the research is the formation of a comprehensive approach to the financial analysis of the equity of an industrial enterprise, which is relevant in the current market conditions of operation of enterprises and covers the analysis of its dynamics, structure, turnover, profitability, risk and its protection. The calculations according to the formed approach have been made on the basis of data of the enterprise of confectionery industry. The practical importance of the work is directed to the application of this method of equity analysis as a tool of financial analysis in the modern conditions of management of industrial enterprises to ensure the efficiency of their activities and management. proach.

Key words: equity, structure, elements of equity, financial analysis, indicators, comprehensive ap-

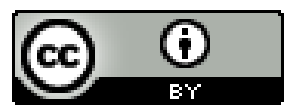

This work is licensed under a Creative Commons Attribution 4.0 International License http://creativecommons.org/licenses/by/4.0/
Statement of the problem and its connection with important scientific and practical tasks. Capital is one of the most used economic categories, which is the basis of creation and development of the enterprise and in the process of functioning it provides the interests of the state, owners and staff. There are different approaches to interpreting this category: capital as a source of income; capital as an accumulated value, capital as an investment resource, capital as a factor of production, and the main reason for the existence of different approaches to the definition of the concept of "capital" is the constant evolution of a market economic system, the multiplicity of aspects of its essence, the various forms in which it occurs $[1$, p. 176], sources of financing, structure of its elements, etc.

As shown by the study [2, p. 32-33], scientists consider the concept of "equity" in terms of economic science, practical features of the enterprise, as well as in the regulatory and legislative field, but analyzing the above provisions, we can conclude that most scientists define capital as an economic category and some real property that can create new products and generate revenue for its owner.

The current state and efficiency of functioning of industrial enterprises, including food processing enterprises, is not possible without a harmonized system of managing own capital, forming its effective structure, determining the normal balance between equity and attracted capital, ensuring the efficiency of its use and risks. Therefore, an important tool and the first step in the process of forming an equity management policy for an industrial enterprise is precisely its complex financial analysis. Conducting such qualitative analysis of equity capital, timely and effective adaptation of approaches to assessing its status, dynamics, structure, efficiency of use and ensuring risks is relevant in the current conditions of influence of internal and external environment on the efficiency of functioning of enterprises, which confirms the relevance of this study.

The analysis of the latest publications on the problem. Such scientists as, O.P. Antonyuk, N.S. Barabash, I.O. Blank, B.V. Burkinsky, N.I. Vlasyuk, N.M. 
Deeva, E.V. Mnykh, G.B. Polyakova, T.M. Stupnitskaya, Yu.S. Tsal-Tsalko, O.O. Sheremet et al. investigated aspects of financial analysis of an enterprise, including its equity, but some issues and aspects of financial analysis are debatable and need further investigation and elaboration. It's true that financial analysis of the enterprise usually covers the main areas [3]: general analysis of financial condition, analysis of financial stability, liquidity and solvency, financial results of the enterprise, bankruptcy, cash flows, business activity of the enterprise, but in the current conditions of loss from the activity of the enterprise and presence of a large number of unprofitable industrial enterprises and small businesses, it is necessary and relevant to conduct a financial analysis of equity capital of businesses.

Forming of the aims of the research. The purpose of this study is to theoretically substantiate the need and formation of a comprehensive approach to the analy- sis of the equity of the enterprise, to determine the aspects of the formation of its individual elements and approaches to its structuring in accordance with regulatory documents. Such analysis was carried out on the basis of the food industry of Odessa region (confectionery industry).

Giving an account of the main results and their substantiation. N(R)AS 1 General Financial Reporting Requirements treats equity as part of the assets of an enterprise that remains after deducting its liabilities [4] and according to which it is structured by the elements: registered (share) capital; contributions to unregistered authorized capital; capital in valuations; additional capital; emission income; accumulated exchange differences; reserve capital; retained earnings (uncovered losses); unpaid capital; capital withdrawn. Other accounting and reporting regulations define the equity of the enterprise differently (table 1).

Table 1

\section{Determination of the essence of the concept of "equity" of the enterprise} in accordance with the regulations [2]*

\begin{tabular}{|l|l|}
\hline \multicolumn{1}{|c|}{ Source } & \multicolumn{1}{c|}{ Defining the essence } \\
\hline $\begin{array}{l}\text { Law of Ukraine "On Accounting and Fi- } \\
\text { nancial Reporting in Ukraine" }\end{array}$ & $\begin{array}{l}\text { Equity is the difference between an enterprise's assets and liabilities } \\
{[5]}\end{array}$ \\
\hline $\begin{array}{l}\text { N(R)AS 1 "General Requirements for Fi- } \\
\text { nancial Reporting" }\end{array}$ & $\begin{array}{l}\text { Equity is the portion of the assets of an enterprise that remains after } \\
\text { deducting its liabilities [4] }\end{array}$ \\
\hline $\begin{array}{l}\text { IAS 1 "Presentation of Financial State- } \\
\text { ments" }\end{array}$ & Generalized quantitative data on the amount classified as equity [6] \\
\hline \multicolumn{2}{|c|}{$*$ Compiled by author based on sources [4-6] }
\end{tabular}

* Compiled by author based on sources [4-6]

In accordance with the Law of Ukraine "On Business Companies" [7] (Article 14), at the expense of retained earnings resulting from economic activity, enterprises create reserve (insurance) capital in the amount specified in the constituent documents: for a joint stock company the amount of reserve capital may not be less than $15 \%$ of the registered capital and must be increased annually by not less than $5 \%$ of the amount of net profit) used in cases of financial difficulties (table 2).
On June 17, 2018, the Law of Ukraine of February 6, 2018 № 2275-VIII “On Limited and Additional Liability Companies” (hereinafter - Law № 2275) came into force. Law № 2275 does not contain any obligation to create and replenish a reserve fund of LLC [8]. Formation of the registered and reserve capital of enterprises of different organizational and legal forms in accordance with the legislative acts are given in table 2.

Table 2

Formation of individual elements of equity of enterprises in accordance with the regulatory acts *

\begin{tabular}{|c|c|c|}
\hline $\begin{array}{c}\text { Legal form } \\
\text { of the enterprise }\end{array}$ & Equity element & Formation of registered and reserve capital \\
\hline \multirow[t]{2}{*}{ Corporations } & Registered capital & $\begin{array}{l}\text { For a joint stock company, the registered capital at the time of its crea- } \\
\text { tion may not be less than the amount equivalent to } 1250 \text { minimum } \\
\text { wages, the amount of the registered capital is equal to the total value } \\
\text { of the shares in accordance with the constituent documents. The paid- } \\
\text { in capital is confirmed by the documents issued by the bank. A com- } \\
\text { pany cannot carry out operations related to its creation unless the } \\
\text { founders have contributed less than } 50 \% \text { of the registered capital. Pri- } \\
\text { vate joint-stock companies (PJSC) and public joint-stock companies } \\
\text { (PJSC) have been distinguished. The number of shareholders in pri- } \\
\text { vate joint stock companies may not exceed } 100 \text { people. }\end{array}$ \\
\hline & Reserve capital & $\begin{array}{l}\text { Due to retained earnings resulting from economic activity, enterprises } \\
\text { create reserve (insurance) capital in the amount specified in the consti- } \\
\text { tuent documents: for a joint stock company the amount of reserve cap- } \\
\text { ital may not be less than } 15 \% \text { of the registered capital and should be } \\
\text { increased annually by no less than } 5 \% \text { of the amount of net income) } \\
\text { used in the event of financial difficulties. }\end{array}$ \\
\hline
\end{tabular}


Continue of table 2

\begin{tabular}{|c|c|c|}
\hline $\begin{array}{c}\text { Legal form } \\
\text { of the enterprise }\end{array}$ & Equity element & Formation of registered and reserve capital \\
\hline & Registered capital & $\begin{array}{l}\text { For full and limited partnerships, limited liability companies and sub- } \\
\text { sidiaries, the minimum size of their authorized capital is not limited. } \\
\text { The number of participants in a limited liability company may not } \\
\text { exceed } 100 \text { people. For private companies the size of the authorized } \\
\text { capital is not established. }\end{array}$ \\
\hline $\begin{array}{l}\text { Full and limited } \\
\text { partnerships, limited } \\
\text { liability companies }\end{array}$ & Reserve capital & $\begin{array}{l}\text { Companies (LLCs) with limited liability and additional liability con- } \\
\text { cerning the obligation to create and replenish the reserve fund of the } \\
\text { LLC are absent. However, the LLC is obliged to form reserve capital } \\
\text { if it has the right to acquire shares in its own share capital without } \\
\text { reducing it by the amount of such share only on condition that on the } \\
\text { day of such acquisition the company will form reserve capital in the } \\
\text { amount of the purchase price of the purchased share, which cannot be } \\
\text { used for making payments in favor of members of such partnership. } \\
\text { Therefore, if the LLC itself buys the participant's share without reduc- } \\
\text { ing the share capital, then it is obliged to form reserve capital at the } \\
\text { price of the acquisition of such (purchased) share. In all other cases, } \\
\text { the creation and replenishment of the reserve capital of the LLC is } \\
\text { optional, but may be determined by the charter documents. Reserve } \\
\text { capital may not be used to make payments to members of such com- } \\
\text { pany, including dividends. }\end{array}$ \\
\hline
\end{tabular}

* Compiled by author based on sources [7-8]

Thus, the peculiarities of forming the constituent components of enterprises are determined by the norms of the legislation in accordance with the organizational and legal forms of enterprises and forms of their owner- ship, as well as the order of formation and movement of equity capital, and it should be noted that the classification of equity depending on the source of formation is very important (fig. 1).

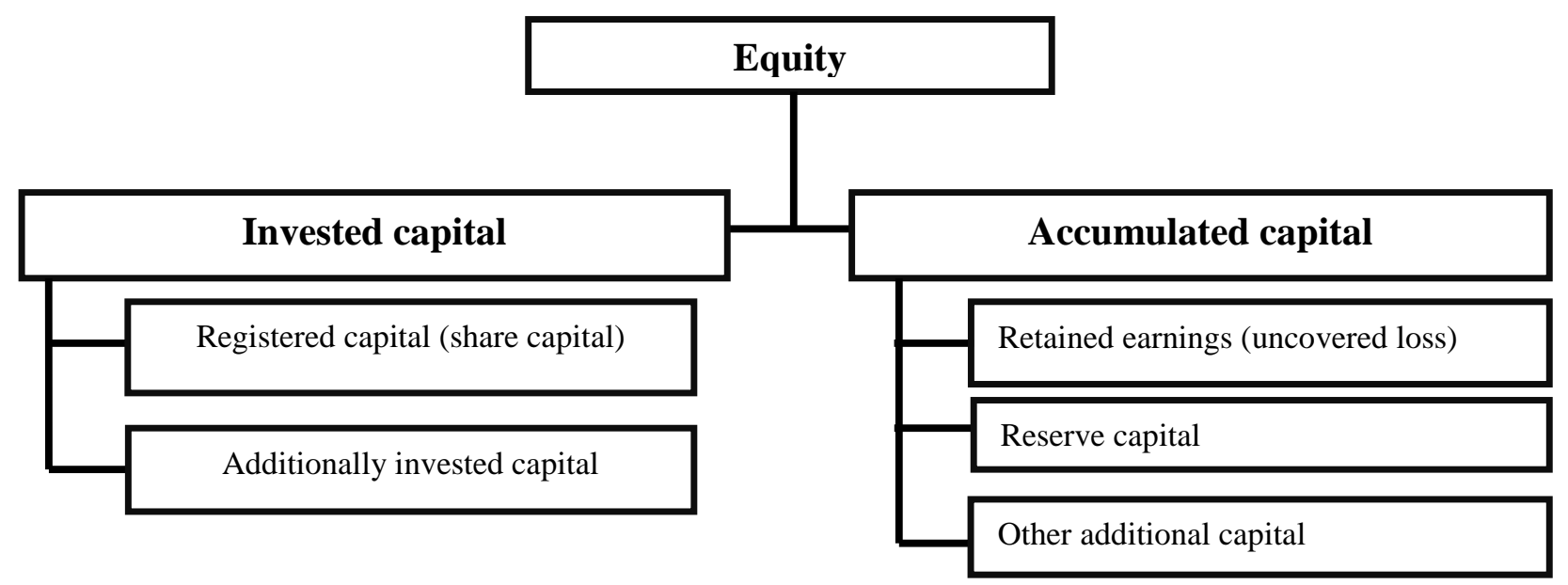

Fig. 1. Classification of equity depending on the source of formation*

* compiled by the author based on the source [4]

It should be noted that the optimum balance between equity and debt remains the debatable question, which ensures the most effective proportionality between the profitability and financial soundness of the enterprise. In the most general form, the concept of "capital structure" is characterized as the ratio of own and borrowed funds that an enterprise uses in the course of its business activities. It's obvious that the ratio of equity to attracted capital in different countries is not the same for determining the financial sustainability of an enterprise: at the enterprises of Japan the attracted capital is $80 \%$ and this is a normal ratio while in European countries, in the USA, in Ukraine, the equity should be at least $50 \%$ of the total capital of the enterprise [9].

It should be noted that the analysis of the capital structure plays an important role in the complex assessment of the financial condition of the enterprise, in particular, its financial stability, because through the analysis of liabilities, such important indicators of the financial condition of the enterprise as: the level of financial autonomy, the level of financial risks, profitability of capital, etc can be evaluated. Thus, the analysis of the compo 
sition, structure and dynamics of equity capital on the example of the confectionery industry is calculated by the authors in table 3 according to the practical approach of classification of equity in accordance with $\mathrm{N}(\mathrm{R}) \mathrm{AS} 1$ [2].

Table 3

Analysis of the composition, structure and dynamics of the equity of the confectionery industry [2]*

\begin{tabular}{|c|c|c|c|c|c|}
\hline \multirow{2}{*}{ Indicators } & \multirow{2}{*}{$\begin{array}{l}\text { Line } \\
\text { code }\end{array}$} & \multirow{2}{*}{ Previous year } & \multirow{2}{*}{$\begin{array}{l}\text { Reporting } \\
\text { year }\end{array}$} & \multicolumn{2}{|c|}{ Deviation } \\
\hline & & & & absolute & $\%$ \\
\hline $\begin{array}{l}\text { Total equity, UAH thousand, } \\
\text { including: }\end{array}$ & 1495 & 9563 & 2519 & -7044 & -73.66 \\
\hline \multirow{2}{*}{$\begin{array}{l}\text { 1. Registered (share) capital, thousand UAH. } \\
- \text { in } \% \text { to equity }\end{array}$} & \multirow[t]{2}{*}{1400} & 10893 & 10893 & - & - \\
\hline & & 113.9 & 432.43 & 318.53 & $\mathrm{x}$ \\
\hline \multirow{2}{*}{$\begin{array}{l}\text { 2. Capital in revaluation, thousand UAH. } \\
\text { - in } \% \text { to equity }\end{array}$} & \multirow[t]{2}{*}{1405} & - & - & - & - \\
\hline & & - & - & - & $\mathrm{x}$ \\
\hline \multirow{2}{*}{$\begin{array}{l}\text { 3. Additional capital, thousand UAH. } \\
\text { - in } \% \text { to equity }\end{array}$} & 1410 & 62916 & 62916 & - & - \\
\hline & & 657.9 & 2497.66 & 1839.76 & $\mathrm{x}$ \\
\hline \multirow{2}{*}{$\begin{array}{l}\text { 4. Reserve capital, thousand UAH. } \\
\text { - in\% to equity }\end{array}$} & 1415 & 6239 & 6239 & - & - \\
\hline & & 65.23 & 247.68 & 182.45 & $\mathrm{x}$ \\
\hline \multirow{2}{*}{$\begin{array}{l}\text { 6. Retained earnings (uncovered loss), } \\
\text { thousand UAH. } \\
\text { - in\% to equity }\end{array}$} & \multirow[t]{2}{*}{1420} & -70485 & -77529 & -7044 & 10,0 \\
\hline & & -737.04 & -3077.77 & -2340.73 & $\mathrm{x}$ \\
\hline \multirow{2}{*}{$\begin{array}{l}\text { 7. Unpaid capital, thousand UAH. } \\
\text { - in } \% \text { to equity }\end{array}$} & 1425 & - & - & - & - \\
\hline & & - & - & - & $\mathrm{x}$ \\
\hline \multirow{2}{*}{$\begin{array}{l}\text { 8. Capital withdrawn, thousand UAH. } \\
\text { - in\% to equity }\end{array}$} & \multirow[t]{2}{*}{1430} & - & - & - & - \\
\hline & & - & - & - & $\mathrm{x}$ \\
\hline
\end{tabular}

* Calculated by the authors on the basis of the financial statements

The table 3 shows that the equity of the enterprise in the reporting year compared with the previous year decreased by $73.66 \%$, which was due to the increase of uncovered loss of the enterprise by $10.0 \%$, which is a negative trend and confirms the need to manage the elements of equity and its structure.
The analysis of the dynamics of the return on capital of the enterprise is carried out according to the forms №1 "Balance sheet (Statement of financial position)", forms № 2 "Statement of financial results (Statement of comprehensive income)" [10] and showed (table 4) that in the reporting year compared to the previous year, the return on capital of the enterprise increased:

Table 4

Analysis of return on capital of the enterprise *

\begin{tabular}{|c|c|c|c|c|}
\hline Indicators & Line code & $\begin{array}{l}\text { Previous } \\
\text { year }\end{array}$ & $\begin{array}{l}\text { Reporting } \\
\text { year }\end{array}$ & $\begin{array}{l}\text { Absolute } \\
\text { deviation }\end{array}$ \\
\hline $\begin{array}{l}\text { 1. Net profit (loss) of the enterprise, thou- } \\
\text { sand UAH. }\end{array}$ & $\begin{array}{c}\text { F. № } 2 \\
\text { code } 2350(2355)\end{array}$ & -15302 & -7044 & 8258 \\
\hline $\begin{array}{l}\text { 2. Average annual capital of the enterprise, } \\
\text { thousand UAH, } \\
\text { including: }\end{array}$ & $\begin{array}{c}\text { F. № } 1 \\
\text { code } 1300\end{array}$ & 43494 & 36189 & -7305 \\
\hline - fixed capital & $\begin{array}{l}\text { F. № } 1, \\
\text { code } 1095\end{array}$ & 9088.5 & 11769 & 2680.5 \\
\hline - working capital & $\begin{array}{l}\text { F. № } 1 \\
\text { code } 1195 \\
\end{array}$ & 34405.5 & 24420 & -9985.5 \\
\hline - including - own working capital & $\begin{array}{c}\text { F. № } 1 \\
\text { code } 1495-\text { code } \\
1095 \\
\end{array}$ & 8125.5 & -5728 & -13853.5 \\
\hline 3. Return on equity, $\%$ & & -35.2 & -19.46 & 15.72 \\
\hline 4. Return on fixed capital, $\%$ & $\mathrm{x}$ & -168.4 & -59.85 & 108.51 \\
\hline 5. Return on working capital, $\%$ & $\mathrm{x}$ & -44.48 & -28.85 & 15.63 \\
\hline 6. Return on equity working capital, \% & $\mathrm{x}$ & -188.32 & $\mathrm{x}$ & $\mathrm{x}$ \\
\hline
\end{tabular}

* Calculated by the authors on the basis of the financial statements

total capital - by $15.72 \%$, due to a decrease in net loss by UAH 8258 thousand. and a decrease in the average annual amount of capital by UAH 730 thousand; fixed capi- tal - by $108.51 \%$ due to the reduction of net loss by UAH 8258 thousand. and from the average annual amount of fixed capital by UAH 2 680,5 thousand; working capital - 
by $15.63 \%$ due to the reduction of net loss by UAH 8258 thousand. and a decrease in the average annual amount of working capital by UAH 9,985.5 thousand; of working capital - by $188.32 \%$ p. at the expense of reducing the net loss by UAH 8258 thousand. and a decrease in the average annual amount of working capital by UAH 13853.5 thousand, these changes rather positively characterize the activity of the enterprise.

The analysis of the financial stability of the enterprise by partial indicators is carried out according to the form № 1 "Balance sheet (Statement of financial position)" using table 5.

Analysis of financial stability of the enterprise by partial indicators *

\begin{tabular}{|c|c|c|c|c|c|}
\hline Indicators & $\begin{array}{l}\text { Algorithm } \\
\text { of calculation } \\
\text { by the line } \\
\text { code }\end{array}$ & $\begin{array}{c}\text { By the beginning } \\
\text { of the previous } \\
\text { year }\end{array}$ & $\begin{array}{l}\text { At the end of } \\
\text { the previous year }\end{array}$ & $\begin{array}{l}\text { At the end } \\
\text { of the report- } \\
\text { ing year }\end{array}$ & Normative value \\
\hline \multirow{2}{*}{$\begin{array}{l}\text { 1. Ratio of autonomy } \\
\left(\mathrm{K}_{\mathrm{ant}}\right)\end{array}$} & 1495 & \multirow{2}{*}{0.5} & \multirow{2}{*}{0.26} & \multirow{2}{*}{0.07} & \multirow{2}{*}{ more 0,5} \\
\hline & 1900 & & & & \\
\hline \multirow{2}{*}{$\begin{array}{l}\text { 2. Ratio of relation- } \\
\text { ship of attracted and } \\
\text { own funds }\left(K_{f}\right)\end{array}$} & $\begin{array}{c}1595+1695+ \\
+1700\end{array}$ & \multirow[t]{2}{*}{1.02} & \multirow[t]{2}{*}{2.84} & \multirow[t]{2}{*}{13.15} & \multirow[t]{2}{*}{ less 1,0} \\
\hline & 1495 & & & & \\
\hline $\begin{array}{l}\text { 3. Availability of } \\
\text { own current as- } \\
\text { sets }\left(\mathrm{K}_{\mathrm{aca}}\right)\end{array}$ & $\begin{array}{c}1495-1095 \text { або } \\
1495+1595- \\
1095\end{array}$ & 14763 & 1488 & -12944 & magnification \\
\hline \multirow{2}{*}{$\begin{array}{l}\text { 4. Equity maneuve- } \\
\text { rability factor }\left(\mathrm{K}_{\mathrm{man}}\right)\end{array}$} & $1495-1095$ & \multirow{2}{*}{0.6} & \multirow{2}{*}{0.16} & \multirow{2}{*}{-5.13} & \multirow{2}{*}{$0,4 \ldots 0,6$} \\
\hline & 1495 & & & & \\
\hline \multirow{2}{*}{$\begin{array}{l}\text { 5. Security ratio of } \\
\text { working capital with } \\
\text { own current assets } \\
\text { (Ks) }\end{array}$} & $1495-1095$ & \multirow[b]{2}{*}{0.37} & \multirow[b]{2}{*}{0.05} & \multirow[b]{2}{*}{-0.64} & \multirow[b]{2}{*}{0,1} \\
\hline & $1195+1200$ & & & & \\
\hline
\end{tabular}

Thus, the coefficient of autonomy (table 5) during the period under study is not within the norm, indicating the instability and financial dependence of the enterprise on external creditors. The ratio of attracted and own funds is not within the normal range either and shows that the enterprise at the beginning of the previous year by 1 UAH. equity attracted UAH 1.02. loans, at the end of the previous year - UAH 2.84, at the end of the reporting year - already UAH 13.15; the value of this indicator increases to 13.15 , which negatively characterizes the activity of the enterprise. The enterprise has its own working capital in the previous year, the value of which decreases and is negative at the end of the reporting year, which caused a decrease in the value of the maneuverability of equity capital at the end of the reporting year. The value of the working capital provision ratio with own working capital has an unstable value during the previous year and a negative value in the reporting one. Thus, the analysis of indicators of financial stability of the enterprise allows to conclude about ineffective investment of funds in the activity of the enterprise and financial instability of functioning of the enterprise. It should be noted that in the current conditions of receiving damage from the activity of the enterprise and presence of a large number of unprofitable industrial enterprises and small business is a partial phenomenon, which proves the need to use financial analysis of the equity of the enterprise, which usually covers the main areas: a general analysis of the financial condition, analysis of financial stability, liquidity and solvency, financial results of the enterprise activity, probability of bankruptcy, cash flows, business activity of the enterprise.

The above financial analysis of equity in the framework of assessing the financial stability and business activity of the enterprise is traditional, and it should be supplemented with equity indicators that allow to systematize information about the protection and efficiency of use of equity of an industrial enterprise in its work and includes separate indicators of business activity, profitability. Finding values within the norm is important for the shareholders of the company [11].

It's true that the Equity Protection Ratio (EPR) is the ratio of the amount of additional and reserve capital to the amount of equity [11]:

$$
K_{E P R}=\frac{(\text { liability balance sheet line } 1410+\text { liability balance sheet line 1415) }}{\text { liability balance sheet line } 1495}
$$

Equity Risk Ratio (ERR) is the ratio of the difference between equity and additional and reserve capital to additional and reserve capital [11]:

(liability balance sheet line 1495 - liability balance sheet line 1410 - liability balance sheet line 1415)

\footnotetext{
$K_{R R}=\frac{\text { (liability balance sheet line } 1410+\text { liability balance sheet line } 1415)}{\text { (ind }}$
} 
Registered Capital Protection Ratio (RCPR) is defined as the ratio of reserve capital to authorized capital [11]:

$$
K_{R C P R}=\frac{\text { liability balance sheet line } 1415}{\text { liability balance sheet line } 1495}
$$
profit [11]:

Self-financing ratio is defined as the ratio of reserve capital growth and retained earnings to the amount of net

(liability balance sheet line 1415 in the current year + liability balance sheet line

1420 in the current year - liability balance sheet line 1415 in the previous year + liability balance sheet line 1420 in the previous year)

$K_{D E}=$

line 2350 of the income statement

Return on Equity (RE) means the ratio of net income to the average annual amount of equity of an enterprise [11]:

line 2350/2355 of the income statement

$K_{R E}=\overline{(0.5 \times(\text { liability balance sheet line } 1495 \text { in the current year }+ \text { liability balance sheet line }}$

1495 in the previous year)) $\times 100 \%$

Equity turnover (ET) is the ratio of net income from sales to the average annual amount of equity [11]:

line 2000 of the income statement

$K_{E T}=(0.5 \times($ liability balance sheet line 1495 in the current year + liability balance sheet

line 1495 in the previous year))

Equity gains (EG) are defined as the difference between the amount of equity in the current year and the previous year [11]:

$E G=\quad$ liability balance sheet line 1495 in the current year-liability balance sheet line 1495 in the previous year

The cost of equity according to the income approach is equal to the ratio of net income to the average annual amount of equity, that is, in fact, equal to the value of the return on equity.
Thus, these indicators allow to obtain the following information about the status, risks and protection of equity of an industrial enterprise [11] table 6.

Table 6

Analysis of enterprise equity $*$,**

\begin{tabular}{|l|c|c|c|}
\hline \multicolumn{1}{|c|}{ Indicators } & The previous year & Reporting year & Deviation \\
\hline 1. Equity protection ratio (Kpr); (1410+1415)/1495 & 7,23 & 27,45 & 20,22 \\
\hline $\begin{array}{l}\text { 2. Equity risk ratio (Krr); (1495-1410-1415)/ } \\
\text { (1410+1415) }\end{array}$ & $-0,86$ & $-0,96$ & $-0,04$ \\
\hline $\begin{array}{l}\text { 3. Registered Capital Protection Ratio (Krcpr); } \\
\text { 1415/1495 }\end{array}$ & 0,65 & 2,48 & 1,83 \\
\hline $\begin{array}{l}\text { 4. The coefficient of development of the enterprise } \\
\text { (Kde); (1415+1420-1415+1420)/2350 }\end{array}$ & Loss * & $-1,17^{*}$ & $-0,28^{*}$ \\
\hline $\begin{array}{l}\text { 5. Return on equity (Kre); } \\
\text { (2350/2355)/(0,5×1495(2017)+1495(2016) } \times 100 \%\end{array}$ & $-0,89 *$ & 2,75 & 0,56 \\
\hline $\begin{array}{l}\text { 6. Equity turnover (Ket); } 2000 /(0,5 \times \\
\text { (1495(2017)+1495(2016)) }\end{array}$ & 2,19 & & \\
\hline
\end{tabular}

* Loss-making activity of the enterprise

** Calculated by the authors on the basis of the financial statements

As shown by the calculation in the reporting year, compared to the previous one, the equity protection ratio increased by 20.22 , due to a decrease in equity al- most four times, which is negative. The ratio of equity development tends to decrease at the expense of increasing the retained earnings of the enterprise. The coefficient 
of protection of the registered capital increased by 1.83 UAH. reserve capital for $1 \mathrm{UAH}$. equity, which is negative. The coefficient of development of the enterprise for the period 2016-2017. and return on equity are negative due to the loss-making activities of the enterprise which has no development paths and are close to bankruptcy. Equity turnover ranges from 2.19 to 2.75 turnover, but with a reduction in the company's net income and equity.

Thus, a systematic approach to managing an enterprise's equity, forming an effective management policy for competitiveness in today's conditions,includes the first stage, which in our opinion, is a qualitative comprehensive financial analysis of the previous period, that includes the analysis of the composition, structure and dynamics of the company's equity; analysis of financial stability indicators of the enterprise, characterizing the equity of the enterprise and its relation with attracted funds; analysis of the relative indices of equity: risk ratio of equity; enterprise development; return on equity; equity turnover; increase in equity.

Conclusions and prospects of the further investigations. As a result of the study of theoretical and practical aspects of the category "equity", its structure in accordance with regulations and legal acts, as well as the formation of its individual elements, aspects of conducting qualitative financial analysis on the basis of a systematic approach, we can draw the following conclusions:

1. The current state and efficiency of functioning of industrial enterprises, including food processing enterprises, are not possible without a harmonized system of managing own capital, forming its effective structure, determining the normal balance between equity and attracted, ensuring the efficiency of its use and risks, therefore an important tool and the first a step in the process of forming a policy of managing equity for an industrial enterprise is precisely its complex financial analysis.

2. Financial analysis of the enterprise, as a rule, covers the main areas: general analysis of financial condition, analysis of financial stability, liquidity and solvency, financial results of the enterprise, bankruptcy, cash flows, business activity of the enterprise, but in the present conditions of receiving damage from the enterprise and the large number of unprofitable industrial enterprises and small businesses, a financial and equity analysis of the enterprise's capital is necessary and relevant.

3. Analysis of the equity structure based on the financial statements of the enterprise indicates a negative trend: the equity of the enterprise decreases, in particular by increasing the uncovered loss, indicators of financial condition and return on capital have a negative tendency and indicate the crisis financial condition of the enterprise, which confirms the need for effective management policies and conducting a comprehensive financial analysis.

4. The sustainable development of domestic enterprises, ensuring their efficiency and competitiveness in modern conditions requires a systematic approach to managing the equity of the enterprise, the formation of an effective management policy, the first stage of which is a qualitative comprehensive financial analysis in the previous period, which was formed and analyzed in this work, namely: analysis of the composition, structure and dynamics of the company's own capital; analysis of financial stability indicators of the enterprise, characterizing the equity of the enterprise and its relation with attracted funds; analysis of the relative indices of equity: risk ratio of equity; enterprise development; return on equity; equity turnover; increase in equity.

5. The further direction of the research when conducting a complex financial analysis of equity of industrial enterprises is the formation of groups of indicators and the scale of their assessment and the type of equity.

\section{References}

1. Petryshynets, L. V. (2011). Systematyzatsiia pidkhodiv do vyznachennia zmistu ta vydiv kapitalu pidpryiemstva. Naukovyi Visnyk Uzhhorodskoho Universytetu, (2), 175-180.

2. Markova, T., Volodina, O., Mytrofanov, O., \& Chehlatonieva, A. (2019). Equity capital: Approaches to Definition, Classification and its Structure. Food Industry Economics, 11(2), 31-37. doi: 10.15673/fie.v11i2.1392

3. Antoniuk, O. P., Stupnytska, T. M., \& Kuprina, N. M. (2015). Ekonomichnyi analiz. Lviv: Mahnoliia 2006.

4. Zahalni vymohy do finansovoi zvitnosti: Natsionalne polozhennia (standart) bukhhalterskoho obliku №1: zatv. nakazom Minfinu vid 07.02.2013 r. № 73 za stanom na 31.05.2019 r. (2019). Retrieved February 7, 2020, from https://zakon.rada.gov.ua/laws/show/z0336-13

5. Pro bukhhalterskyi oblik ta finansovu zvitnist v Ukraini: Zakon Ukrainy vid 16.07.99 r. № 996-XIV za stanom na 16.01.2020r. (2020). Retrieved February 7, 2020, from https://zakon.rada.gov.ua/laws/show/996-14

6. Podannia finansovoi zvitnosti: Mizhnarodnyi standart bukhhalterskoho obliku № 1. (2012). Retrieved February 7, 2020, from http://zakon1.rada.gov.ua/laws/show/929_013/paran2\#n2

7. Pro hospodarski tovarystva: Zakon Ukrainy vid 19.09.91 r. № 1576- XII za stanom na 06.02.2018 r. (2018). Retrieved January 6, 2020, from https://zakon.rada.gov.ua/laws/show/1576-12

8. Pro tovarystva $\mathrm{z}$ obmezhenoiu ta dodatkovoiu vidpovidalnistiu: Zakon Ukrainy vid 06.02.2018 r. № 2275 VIII za stanom na 03.10.2019 r. (2019). Retrieved January 6, 2020, from https://zakon.rada.gov.ua/laws/show/2275-19 
9. Stupnytska, T. M. (2015). Finansovyi analiz z ohliadu na ymovirnist bankrutstva pidpryiemstva. In V. V. Nemchenko (Ed.), Oblikovo-analitychne zabezpechennia v umovakh upravlinnia finansovo-ekonomichnoiu bezpekoiu pidpryiemstva (pp. 105-112). Odesa: Feniks.

10. Tsal-Tsalko, Yu. S. (2008). Finansovyi analiz. Kyiv: TsUL.

11. Kobyletskyi, V. R. Metodyka rozrakhunku pokaznykiv vlasnoho kapitalu. Onlain-Zhurnal «Financial Analysis Online». Retrieved from https://www.finalon.com/metodyka-rozrakhunku/92-analiz-vlasnoho-kapitalu-ua

Received 19 January 2020

Approved 2 February r 2020

Available in Internet 31.03.20

Куприна Н.М.

кандидат экономических наук, доцент кафедра учета и аудита

E-mail:k.natali_@ukr.net

ORCID ID: 0000-0003-4645-545X

\section{Володина Е.П.} ассистент

кафедра иностранных языков

E-mail: volodinaolenaonaft@gmail.com

ORCID ID: 0000-0003-0552-6733
Маркова Т.Д.

кандидат экономических наук, доцент кафедра учета и аудита

E-mail: markova.tetiana17@gmail.com

ORCID ID: 0000-0002-9437-2635

\section{Ступницкая М.И.}

студентка 4 курса фракультета менеджмента, маркетинга и логистики

Одесская национальная академия пищевых технологий ул. Канатная, 112, г. Одесса, Украина, 65039

E-mail: marino4ka036@gmail.com

ORCID ID: 0000-0003-0736-6411

\section{ОСОБЕННОСТИ АНАЛИЗА СОБСТВЕННОГО КАПИТАЛА ПРЕДПРИЯТИЯ В СОВРЕМЕННЫХ УСЛОВИЯХ}

В статье рассматривается структура собственного капитала предприятия, определения и формирования отдельных его элементов, таких как зарегистрированный и резервный капитал, в соответствии с нормативными бухгалтерскими документами и законодательными актами Украины. Рассмотрена классификация собственного капитала (вложенный и накопленный капитал) предприятия по Национальному (Положению) стандарту бухгалтерского учета 1 «Общие требования к финансовой отчетности» и по источникам его формирования. Определено, что соотношение собственного и привлеченного капитала в различных странах для определения финансовой устойчивости предприятия является различным и колеблется от $50 \%$ до $80 \%$ нормативного значения. Поэтому вопросы защиты и минимизации риска собственного капитала и развития собственного капитала в современных рыночных условиях в Украине вызывают необходимость учета при оценке собственного капитала (в частности, в пищевой промышленности - коэффрициент защиты собственного капитала и коэффициент риска собственного капитала).

В результате проведенной оценки состава, структуры и динамики собственного капитала, оценки рентабельности, оценки фринансовой устойчивости по частным показателям, оценки показателей собственного капитала, определена необходимость непрерывного контроля и управления элементами собственного капитала и его структурой. Проанализированы и обоснованы необходимость формирования и использования комплексного подхода для проведения финансового анализа собственного капитала предприятия в системе управления им.

Научным результатом исследования является формирование комплексного подхода к финансовому анализу собственного капитала промышленного предприятия, что является актуальным в современных рыночных условиях функционирования предприятий и охватывает анализ его динамики, структуры, оборачиваемости, рентабельности, риска и его защиты. Проведены расчеты по предложенному подходу на основе данных предприятия кондитерской отрасли.

Практическая значимость работы направлена на применение данного метода анализа собственного капитала, как инструмента финансового анализа в современных условиях хозяйствования промышленных предприятий, для обеспечения эффективности их деятельности и управления.

Ключевые слова: собственный капитал, структура, элементы собственного капитала, фиинансовый анализ, показатели, комплексный подход. 
Купріна Н.М.

кандидат економічних наук, доцент кафедра обліку та аудиту E-mail:k.natali@ @ukr.net ORCID ID: 0000-0003-4645-545X

\section{Володіна О.П.} асистент кафедра іноземних мов

E-mail: volodinaolenaonaft@gmail.com ORCID ID: 0000-0003-0552-6733
Маркова Т.Д.

кандидат економічних наук, доцент кафредра обліку та аудиту

E-mail: markova.tetiana17@gmail.com ORCID ID: 0000-0002-9437-2635

\section{Ступницька М.I.}

студентка 4 курсу фракультету менеджменту, маркетингу та логістики

Одеська національна академія харчових технологій вул. Канатна 112, м. Одеса, Україна, 65039 E-mail:marino4ka036@ gmail.com ORCID ID: 0000-0003-0736-6411

\section{ОСОБЛИВОСТІ АНАЛІЗУ ВЛАСНОГО КАПІТАЛУ ПІДПРИЄМСТВА В СУЧАСНИХ УМОВАХ}

У статті розглядається структура власного капіталу підприємства та визначення й формування окремих його елементів, таких як зареєстрований та резервний капітал, відповідно до нормативних бухгалтерських документів та законодавчих актів України. Розглянута класифікація власного капіталу (вкладений та накопичений капітал) підприємства за Національним (Положенням) стандартом бухгалтерського обліку 1 «Загальні вимоги до фрінансової звітності» та за джерелами його формування. Визначено, що співвідношення власного та залученого капіталу в різних країнах для визначення фінансової стійкості підприємства є різним і коливається від 50\% до $80 \%$ нормативного значення. Тому питання захисту та мінімізації ризику власного капіталу та розвитку власного капіталу в сучасних ринкових умовах в Україні зумовлює необхідність врахування при оцінки власного капіталу, зокрема підприємств харчової промисловості, коефіцієнт захисту власного капіталу та коефіцієнт ризику власного капіталу.

В результаті проведеної оцінку складу, структури та динаміки власного капіталу, оцінку рентабельності, оцінку фрінансової стійкості за частковими показниками, оцінку показників власного капіталу визначено необхідність безперервного контролю та управління елементами власного капіталу та його структурою. Проаналізовано й обґрунтована необхідність формування та використання комплексного підходу для проведення фінансового аналізу власного капіталу підприємства в системі управління ним.

Науковим результатом дослідження є формування комплексного підходу до фінансового аналізу власного капіталу промислового підприємства, що $є$ актуальним в сучасних ринкових умовах функціонування підприємств та охоплює аналіз його динаміки, структури, оборотності, рентабельності, ризику та його захисту. Проведено розрахунки за сформованим підходом на підставі даних підприємства кондитерської галузі.

Практична значущість роботи направлена на застосування даного методу аналізу власного капіталу як інструменту фінансового аналізу в сучасних умовах господарювання промислових підприємств для забезпечення ефективності їх діяльності та управління.

Ключові слова: власний капітал, структура, елементи власного капіталу, фінансовий аналіз, показники, комплексний підхід.

\section{Література}

1. Петришинець Л.В. Систематизація підходів до визначення змісту та видів капіталу підприємства // Науковий вісник Ужгородського університету. Серія Економіка. 2011. № 2. С. 175-180.

2. Markova T., Volodina O., Mytrofanov O., Chehlatonieva A. Equity capital: Approaches to Definition, Classification and its Structure // Food Industry Economics. 2019. Vol 11, № 2. P.31-37. doi: 10.15673/fie.v11i2.1392

3. Антонюк О.П., Ступницька Т.М., Купріна Н.М. Економічний аналіз: навчальний посібник. Львів: Магнолія 2006, 2015. 326 с.

4. Загальні вимоги до фінансової звітності: Національне положення (стандарт) бухгалтерського обліку №1: затв. наказом Мінфіну від 07.02 .2013 p. № 73 за станом на 31.05 .2019 p. URL: https://zakon.rada.gov.ua/laws/show/z0336-13 (дата звернення: 07.01.2020).

5. Про бухгалтерський облік та фінансову звітність в Україні: Закон України від 16.07.99 p. № 996-XIV за станом на 16.01.2020p. / Верховна Рада України. Київ. URL: https://zakon.rada.gov.ua/laws/show/996-14 (дата звернення: 07.01.2020). 
6. Подання фінансової звітності: Міжнародний стандарт бухгалтерського обліку № 1. URL: http://zakon1.rada.gov.ua/laws/show/929_013/paran2\#n2 (дата звернення: 07.01.2020).

7. Про господарські товариства: Закон України від 19.09.91 р. № 1576-XII за станом на 06.02.2018p. URL: https://zakon.rada.gov.ua/laws/show/1576-12 (дата звернення: 06.01.2020).

8. Про товариства з обмеженою та додатковою відповідальністю: Закон України від 06.02.2018 р. № 2275-VIII за станом на 03.10.2019p. URL: https://zakon.rada.gov.ua/laws/show/2275-19 (дата звернення: 06.01.2020).

9. Ступницька Т.М. Фінансовий аналіз з огляду на ймовірність банкрутства підприємства // Обліковоаналітичне забезпечення в умовах управління фінансово-економічною безпекою підприємства: монографія / В.В. Немченко, Ф.А. Трішин, Л.В. Іванченкова, Н.М. Купріна, Г.О. Ткачук та ін. ; за заг. ред. д.е.н., проф. В.В. Немченко. Одеса: Фенікс, 2015. С.105-112.

10. Цал-Цалко Ю.С. Фінансовий аналіз: підруч. К.: ЦУЛ, 2008. 556 с.

11. Кобилецький В.Р. Методика розрахунку показників власного капіталу // Онлайн-журнал «Financial Analysis online». URL: https://www.finalon.com/metodyka-rozrakhunku/92-analiz-vlasnoho-kapitalu-ua (дата звернення: 08.01.2020).

Стаття надійшла 19.01.2020

Стаття прийнята до друку 2.02.2020

Доступно в мережі Internet 31.03.20

Цитування згідно ДСТУ 8302:2015

Kuprina N., Markova T., Volodina O., Stupnytska M. Peculiarities of analysis of enterprise's own capital in modern conditions // Food Industry Economics. 2020. Vol.12, Issue 1. P. 35-44. doi: 10.15673/fie.v12i1.1667

Cite as APA style citation

Kuprina, N., Markova, T., Volodina, O., \& Stupnytska, M. (2020). Peculiarities of analysis of enterprise's own capital in modern conditions. Food Industry Economics, 12(1), 35-44. doi: 10.15673/fie.v12i1.1667 